\title{
Kommentar til innlegget fra professor Träskman
}

\author{
Af Iver Huitfeldt ${ }^{1}$
}

Utviklingen med nedskalering av det nordiske samarbeidet, som professor Träskman er så kritisk til, er nok uavvendelig. Det skyldes - tror jeg - at straff og kriminalpolitikk er gått fra å være »fag« til nettopp å være »politikk«. Partiene anser at de ikke kan være bundet av »Nordic Cooperation«, i stedet gjelder den innenrikspolitiske kampen om velgerne! Straff blir ikke lenger et spørsmål om »fornuftig « kriminalpolitikk, hva som virker og ikke virker på kriminaliteten, men hva som virker på velgerne. Så sent som på 1960-tallet var partiene opptatt av ikke å ha noe om kriminalpolitikk i partiprogrammene, nå er kriminalpolitikk et viktig profileringsområde! Og derfor har vi i Norge fått - etter min mening meningsløst strenge straffer for seksuallovbrudd der det ikke har vært brukt vold, som - selv om forholdet kan være krenkende nok - ikke burde kvalifisere til fire års fengsel.

Utviklingen - tror jeg - begynte på 1960-tallet med berettiget kritikk mot deler av strafferettsystemet. I Norge ble særreaksjonen tvangsarbeid (i løsgjengerloven fra 1900) opphevet i 1970. Særreaksjonen »Arbeidsskole« for unge lovbrytere (på Berg åpnet i 1951) ble nedlagt som mislykket i 1965 etter en rapport fra direktøren selv, psykolog Kåre Bødal. Avløseren »Ungdomsfengsel« - ja, »straff« denne gangen - ble opphevet allerede i 1975. I Norge var foreningen KROM, i Sverige KRIM og i Danmark KRUM(?) sterkt engasjerte pådrivere med det grunnleggende synspunkt at systemet var »urettferdig« og rammet »de svake«, dem var det i stedet »synd på«. Ja, »alle« (vi som er så gamle) husker vel den svenske filmen »Släpp fångarne loss det är vår«! I Norge satte justisminister Inger Louise Valle i gang arbeidet med »Kriminalmeldingen«, som bygget på de samme synspunkter, straff virket ikke, systemet var »urettferdig«. Men før blekket hadde tørket, kom det en motgående bølge, »høyrebølgen« er den kalt i Norge. Likevel, mange av Valles reformer ble gjennomført, samfunnstjeneste, senere samfunnsstraff er nå ansett som en »fornuftig« straffeform.

På lengre sikt har "politikk« fătt stadig større plass i kriminalpolitikken. KROMs og Valles rettferdighetskriterium er snudd og brukes nå som argument for strenge straffer. Ja, »rettferdighet« er som en strikk, det er et kriterium som kan tøyes svært langt! 
Til slutt har jeg lyst til å nevne at den norske Styrkebrønnens sendelag i Moldova, NORLAM - for å bidra til »Rule of Law and Human Rights«-reform i strafferettskjeden - var med på å ta initiativ til en sterk reduksjon av straffenivået der. Da vi kom i 2007 med meg som den første »Head of Mission«, var minimumsstraffen for at stjele verdier tilsvarenden USD 1,000 ti års fengsel. I gjennomsnitt sonet de innsatte i fengslene en straffedom på mer enn ni års fengsel. Der argumenterte vi for straffereduksjon med begrepet »marginal benefit« hentet fra økonomisk teori: Etter å ha nådd et visst nivå vil fordelen av å bruke penger på et formål synke og gå mot null! Som pedagogisk eksempel brukte vi »drinking wine« - for Moldova er kjent for sin gode vin - og pekte på at etter å ha drukket noen glass, vil »grensenytten « av det neste glasset synke. Derfor burde man »think twice« med å utmåle strenge straffer og tenke over nytten av den siste delen av straffen. Ja, vi pekte på at strenge straffer ikke bare kunne savne fornuft med hensyn til å redusere kriminalitet, de kunne til og med være »counterproductive for society«, fordi jo lenger tid i fengsel, dess vanskelige blir resosialiseringen. Vi sammenlignet igjen med alkohol: If after the intended last glass you take one more glass, it is well known that excess consumption of alcohols not only not do you any good, it is harmful!

Kan vi håpe på at våre politikere ikke gjør for mye skade i strevet for velgeroppslutning!

\section{Note}

1. Iver Huitfeldt er pensjonert etter 20 år som lagdommer i Borgarting lagmannsrett, to år hos den norske regjeringsadvokaten, ti år som statsadvokat og førstestatsadvokat i daværende Eidsivating statsadvokatembeter og i ØKOKRIM og før det åtte år underdirektør og leder for sosialavdelingen i Ullersmo landsfengsel.

Han har vært to år i Bosnia og Herzegovina for OSSE og FN, ett år i Moldova for Justits- og Utenriksdepartementet og har siden 2004 vært rådgiver for Utenriksdepartementet $\mathrm{i}$ Menneskerettighetsdialogen mellom Norge og Vietnam. 